\title{
Faunistic Study of Ladybirds (Coleoptera: Coccinellidae) in the Banat Region, Romania
}

\author{
Ana - Maria VIRTEIU ${ }^{*}$, Ioana GROZEA ${ }^{1}$, Ramona STEF ${ }^{1}$, Mihai VLAD $^{1}$ and Ionela DOBRIN² \\ ${ }^{1}$ Department of Biology and Plant Protection, Banat's University of Agricultural Sciences and \\ Veterinary Medicine "King Michael I of Romania" from Timisoara \\ 119 Calea Aradului, Timisoara, Romania \\ ${ }^{2}$ Department of Plant Sciences, University of Agronomic Science and Veterinary Medicine Bucharest 59 \\ Marasti Bvd, Sector 1, Bucharest, Romania \\ *Corresponding author: anamaria.badea@gmail.com
}

Bulletin USAMV series Agriculture 72(2)/2015

Print ISSN 1843-5246; Electronic ISSN 1843-5386

DOI 10.15835/buasvmcn-agr: 11489

\begin{abstract}
Ladybirds (Coccinellidae) are a popular, widely recognized and highly regarded insect group due to their bright color and role in controlling insect pests. Worldwide nearly 6000 species are known. From systematic point of view, ladybeetles belonging to Class Insecta, Subclass Pterygota, Order Coleoptera, Suborder Polyphaga, Superfamily Cucujoidea anf Family Coccinellidae. Coccinellids are of interest and importance in agriculture and forestry, since adults and larvae of most species are predators of herbivorous pests such aphids, psyllids, mealy bugs and scale insects. The aim of this research regarding coccinellid beetles was to explore, identify and also characterize the coccinellid fauna of the Banat region (Romania). The coccinellid beetles were collected from March 2013 to September 2014 from 4 localities at different altitudes in the Banat region. Samples were collected at weekly interval from a wide variety of habitats: agricultural land, gardens and parks, both on herbaceous and woody essences. In this study a total of 15 species belonging to 11 genera and 3 subfamilies were identified. In the investigated habitats from the entomofaunistic point of view, the coccinelid species identified were as follows: Coccinella 5 - punctata L., Coccinella 7 - punctata L., Coccinulla 14 - pustulata L., Tythaspis 17 - punctata L., Adalia 2 - punctata L., Adalia 10 - punctata L., Propylaea 14 - punctata L., Subcoccinella 24 - punctata L., Psylobora 22 punctata L., Hippodamia tredecimpunctata L., Adonia variegate Goeze., Harmonia axyridis Pallas., Calvia decimguttata L., Chilocorus bipustulatus L. and Chilocorus renipustulatus Scriba. Seven species were the most abundant and could be observed in the investigated area every year.
\end{abstract}

Key words: Banat region, Coccinellidae, environmental factors, faunistic study, feeding habits.

\section{INTRODUCTION}

The beetle family Coccinellidae is a wellknown, abundant and diverse family (Majka \& McCorquodale, 2010). From a human perspective ladybirds are one of the most beautiful insects (Gordon, 1985).

This family belongs to superfamily Cucujoidea and are a large family with about 6000 species described worldwide (Vandenberg, 2002; Khormizi et al., 2013). There are seven subfamilies of coccinellidae: Coccidulinae, Coccinellinae,
Scymninae, Chilochorinae, Ortalinae, Sticholotidinae and Epilachninae (Vandenberg, 2002). Most of this coccinellids are bright shining colors with a pattern of spots or patches against a contrasting background. Many appear to be distasteful to birds and their conspicuous appearance is an exemple of warning coloration (Moreton, 1969).

The coccinellidae are an important group of beetles from both an economic standpoint in their use as biological control agent and in their diversity and adaptation to a number of differing 
habitats (Debach, 1974; Michels, 1987; Jafari et al., 2013). They are environmentally beneficial and have been used in different parts of the world to control pests such as aphids, mealybugs, thrips, scale insects etc (Majerus, 1985, Ansari Pour, 2012).

\section{MATERIALS AND METHODS}

The coccinellid beetles were collected from March 2013 to September 2014 from 4 localities at different altitudes in the Banat region. Samples were collected at weekly interval from a wide variety of habitats: agricultural land, gardens and parks, both on herbaceous and woody essences. Entomological material that is the subject of this study was collected as follows: Gătaia, the first locality - the experimental field was located on a family farms, the ladybirds collection was made from alfalfa culture; Timisoara, the second locality - the experimental field was represented by the green spaces between apartment buildings and parks in town; Jimbolia, the third locality the experimental fields were represented by the fields belonging to SC Westland Company SRL, the wheat crop; and the forth locality, Făget - the experimental field was represented by green areas and wooded areas surrounding the city.

The specimens present on herbaceous plants were collected using a standard entomological net (on a plot 25 double sweeps for each repetition were performed, they were used 3 repetitions / experience) and those present on different species of tree or shrub using a beating tray (Japanese umbrellas) - the collection procedure was marking the location, geographical coordinates (using a GPS device), and the name of the tree or shrub species from which was made the insect collection; for each location (park, green space, garden) were randomly selected 5 species of trees and shrubs (depending on the availability of the area) that were collected insects.

The collected ladybirds were taken to laboratory. The adults of each species were carefully studied under binocular microscope in order to determine the scientific name of the species. Gender systematic classification of species was made using phylogenetic sequence by Gordon (1985), and also using the superior classification after Vandenberg (2002) and Lawrence et al. (1995).

\section{RESULTS AND DISCUSSION}

Insect biodiversity research group, in our case Coccinellidae family is extremely important because it determines not only their number, but also the changes that occur in numbers in certain habitats. Ecosystems, namely agro-ecosystems in which they practice intensive agriculture have undergone major changes over the last decade, thereby affecting the structure of fauna of insects, not only insects, but all living organisms.

In this context, our research aim is to highlight the species of coccinellidae fauna present in different habitats in Timis County (Tab. 1). The composition in species of coccinellidae fauna is largely determined by climatic factors and can vary greatly from one locality to another. The microclimate conditions influence through plant density, density of predators, annual changes in abundance of insect species, and differences in the rate and time when the population migration occurs.

Insects collected from Timisoara, Gataia, Jimbolia and Faget is a typical example of the coccinellidae fauna present in western Romania. The first species collected from the field were Coccinella septempunctata and Adonia variegata. Seasonal variation in terms of the number of coccinellid species was affected primarily by climatic conditions, the density of crops (we refer to alfalfa and wheat), and the availability of food resources.

In samples collected in period $2013-2014$ they were identified a total of 427 specimens belonging to 15 species and 3 subfamilies (Tab. $1)$, of which the most abundant species were Coccinella septempunctata $(n=113)$ - represents $26.46 \%$ of the total number of collected insects. Next dominant species was Propylaea quatordecimpunctata $(n=56)$ - represents $13.11 \%$ of the total collected insects. Dominant species were also Adalia bipunctata $(n=55)$ and Adonia variegata $(n=57)$ - represent $12.88 \%$ and $12.41 \%$ of all insects collected.

Four species of coccinellids (Harmonia axyridis, Adalia decimpunctata, Calvia decemguttata, Coccinula quatordecimpustulata) had an medium abundance ( $n=20-37)$, while seven species (Subcoccinella vigintiquatorpunctata, Chilocorus bipustulatus, Coccinella quinquepuncta, Hippodamia tredecimpunctata, Psyllobora vigintiduopunctata, Tytthaspis sedecimpunctata 
and Chilocorus renipustulatus) were rare ( $n=1-$ 12).

The adults of 3 coccinellids species: Chilocoris renipustulatus, Coccinella quinquepunctata and Harmonia axyridis were collected only in Timisoara, while 2 species Hippodamia tredecimpunctata and Subcoccinella vigintoquatorpunctata were found in Gătaia. During the growing season of 2013 and 2014, the larvae of several species of insects belonging to the Coccinellidae family were seen feeding on vegetation in the area studied, but they are not our goal in this research.

It is known that Coccinele quinquepunctata prefer woody essences, so its presence only in Timisoara area is explicable, this species hibernates under plant debris or in the edge of forests.

The species Adonia variegata and Hippodamia tredecimpunctata are characteristic of cereal crops, so their presence in fields from Gătaia and Jimbolia is solely entitled. Species Adonia variegata was more abundant in the Jimbolia area than in Gătaia.

Comparing the data with those of the literature found that coccinelids species identified in the 4 studied areas in western Romania coincides largely with those found by other authors who studied nearby in Serbia, Hungary and Romania (Lövei, 1981; Thalji, 2006, Lisenchi Murariu, 2008). In the literature studied, the species Coccinella septempunctata was regarded as the species with the highest abundance and frequency of coccinellid predatory species, as has also been demonstrated in this study.

Current knowledge on zoogeographical distribution of insect species belonging to Coccinellidae family in western Romania can be considered satisfactory.

Tab. 1. The insect species belonging to Coccinellidae family and the number of specimens collected from the four locality in western Romania, in 2013 - 2014 period

\begin{tabular}{|c|c|c|c|c|c|c|}
\hline Family & Species & Timisoara & Gataia & Făget & Jimbolia & $\begin{array}{c}\text { Total number } \\
\text { of specimen }\end{array}$ \\
\hline \multirow{16}{*}{ Coccinellidae } & Chilocorus bipustulatus & 7 & - & 2 & - & 9 \\
\hline & $\begin{array}{l}\text { Chilocorus } \\
\text { renipustulatus }\end{array}$ & 1 & - & - & - & 1 \\
\hline & Adalia bipunctata & 21 & 12 & 1 & 21 & 55 \\
\hline & Adalia decimpunctata & 5 & 4 & 11 & 2 & 22 \\
\hline & Calvia decemguttata & 9 & - & 7 & 5 & 21 \\
\hline & $\begin{array}{c}\text { Coccinella } \\
\text { quinquepuncta }\end{array}$ & 8 & - & - & - & 8 \\
\hline & $\begin{array}{c}\text { Coccinella } \\
\text { septempunctata }\end{array}$ & 33 & 27 & 35 & 18 & 113 \\
\hline & $\begin{array}{c}\text { Coccinula } \\
\text { quatordecimpustulata }\end{array}$ & - & 11 & - & 9 & 20 \\
\hline & Harmonia axyridis & 37 & - & - & - & 37 \\
\hline & Adonia variegata & 3 & 17 & 5 & 28 & 53 \\
\hline & $\begin{array}{c}\text { Hippodamia } \\
\text { tredecimpunctata }\end{array}$ & - & 5 & - & 3 & 8 \\
\hline & $\begin{array}{c}\text { Propylaea } \\
\text { quatordecimpunctata }\end{array}$ & 16 & 31 & 5 & 4 & 56 \\
\hline & $\begin{array}{c}\text { Psyllobora } \\
\text { vigintiduopunctata }\end{array}$ & 2 & 3 & - & 2 & 7 \\
\hline & $\begin{array}{c}\text { Tytthaspis } \\
\text { sedecimpunctata }\end{array}$ & - & 2 & - & 3 & 5 \\
\hline & $\begin{array}{c}\text { Subcoccinella } \\
\text { vigintiquatorpunctata }\end{array}$ & - & 12 & - & - & 12 \\
\hline & & & & & Total & 427 \\
\hline
\end{tabular}


General characteristics of coccinellidae fauna in the studied area is characterized by zoogeographic point of view as is shown in table 2 .

The chorological categories were made with direct reference to species level and based on a well-structured classification. Zoogeographical distribution is made after Serafim and Maican (2004).

As far as chorology is concerned there are 9 Palaearctic species, 2 cosmopolitan species, 1 South - Palaearctic species, a Eurasian species, 1 West - Palaearctic species and 1 Holarctic species.

Coccinellids species have specific food habits and food source has an immediate effect on development.

Three major categories of feeding habits generally are recognized in the areas under study: - predation (zoophagy) - 12 species of coccinellids have a zoophagous food regime, 7 of which consume aphids (aphidophagous), 4 species consume aphids and psyllids (Psylla sp.) and a single species eat only psyllids;

- fungus feeding (mycophagy) - Tytthaspis sedecimpunctata have a mycophagous feeding regime;

- plant feeding (phytophagy) - Subcoccinella vigintiquatorpunctata, consume plant tissues; Psyllobora vigintiduopunctata species has both phytophagous and mycophagous feeding regime (Tab. 3).

Studies by Pemberton and Vandenberg (1993), Hodek (1973, 1996), Moser et al. (2008), Lundgren et al. (2009) and Giorgi et al. (2009) suggest that species generally regarded as predaceous may regularly supplement their basic diet with small amounts of leaf material even in the presence of abundant prey and water (zoophytophagy).

Polyphagy also occurs among at least some mycophagous coccinellids which often complement their diet with pollen (Anderson,1982; Ricci, 1982, 1986; Ricci et al., 1983; Giorgi et al.,2009).

Since insects of Coccinellidae family shows significant differences regarding diet, they can be a good barometer of biodiversity; the species richness of this family being in close correlation with the overall diversity of fauna.

Most species collected are zoophagous, the most numerous being aphidophagous, and some of them consuming psyllids or scale insects, having as host hundreds of species of plants, both herbaceous and woody essences. Only a few species have a phitophagous feeding regime.

In assessing the number of specimens, the collecting of insects from forests surrounding areas (Făget) has not meant a considerable source of ladybugs that colonize plant species. Oviposition

Tab. 2. Zoogeographical distribution of insect species belonging to Coccinellidae family, collected from the four locality in western Romania, in 2013 - 2014 period

\begin{tabular}{|c|c|c|c|c|c|}
\hline \multirow{2}{*}{ Classification } & \multirow{2}{*}{$\begin{array}{l}\text { Zoogeographical distribution } \\
\text { (region) }\end{array}$} & \multicolumn{4}{|c|}{ Locality } \\
\hline & & Timisoara & Gataia & Făget & Jimbolia \\
\hline Chilocorus bipustulatus & South - Palaearctic & $*$ & & $*$ & \\
\hline Chilocorus renipustulatus & Palaearctic & $*$ & & & \\
\hline Adalia bipunctata & Cosmopolitan & $*$ & $*$ & $*$ & $*$ \\
\hline Adalia decimpunctata & Palaearctic & $*$ & $*$ & $*$ & $*$ \\
\hline Calvia decemguttata & Palaearctic & $*$ & & $*$ & $*$ \\
\hline Coccinella quinquepuncta & Palaearctic & $*$ & & & \\
\hline Coccinella septempunctata & Palaearctic & $*$ & $*$ & $*$ & $*$ \\
\hline Coccinula quatordecimpustulata & Eurasia & & $*$ & & $*$ \\
\hline Harmonia axyridis & West - Palaearctic & $*$ & & & \\
\hline Adonia variegata & Palaearctic & * & * & * & $*$ \\
\hline Hippodamia tredecimpunctata & Holarctic & & $*$ & & $*$ \\
\hline Propylaea quatordecimpunctata & Palaearctic & $*$ & $*$ & $*$ & $*$ \\
\hline Psyllobora vigintiduopunctata & Palaearctic & $*$ & $*$ & & $*$ \\
\hline Tytthaspis sedecimpunctata & Palaearctic & & $*$ & & $*$ \\
\hline Subcoccinella vigintiquatorpunctata & Cosmopolitan & & $*$ & & \\
\hline
\end{tabular}


Tab. 3. Feeding habits of insect species belonging to Coccinellidae family, collected from the four locality in western Romania, in 2013 - 2014 period

\begin{tabular}{|c|c|c|c|c|}
\hline \multirow{3}{*}{ Classification } & \multicolumn{4}{|c|}{ Feeding habits } \\
\hline & \multicolumn{2}{|c|}{ Zoophagy } & \multirow{2}{*}{ Mycophagy } & \multirow{2}{*}{ Phytophagy } \\
\hline & Aphids & Psyllids & & \\
\hline Chilocorus bipustulatus & $*$ & & & \\
\hline Chilocorus renipustulatus & $*$ & & & \\
\hline Adalia bipunctata & $*$ & & & \\
\hline Adalia decimpunctata & $*$ & & & \\
\hline Calvia decemguttata & $*$ & $*$ & & \\
\hline Coccinella quinquepuncta & & $*$ & & \\
\hline Coccinella septempunctata & $*$ & $*$ & & \\
\hline Coccinula quatordecimpustulata & $*$ & & & \\
\hline Harmonia axyridis & $*$ & $*$ & & \\
\hline Adonia variegata & $*$ & $*$ & & \\
\hline Hippodamia tredecimpunctata & $*$ & & & \\
\hline Propylaea quatordecimpunctata & $*$ & & & \\
\hline Psyllobora vigintiduopunctata & & & $*$ & $*$ \\
\hline Tytthaspis sedecimpunctata & & & $*$ & \\
\hline Subcoccinella vigintiquatorpunctata & & & & $*$ \\
\hline
\end{tabular}

by the hibernating females and larvae survival is directly correlated with climate changes and availability of food source, so a large population of aphids can sustain a significant number of coccinelide. So, as a conclusion, the ladybugs in lack of food can migrate long distances in search of it.

\section{CONCLUSION}

The diversity of the coccinellidae fauna is largely determinate by the evolution of the environmental factors and feeding habits.

The most abundant species of insects belonging to Coccinellidae family was Coccinella septempunctata (26.46\%).

As far as chorology is concerned there are 9 Palaearctic species, 2 cosmopolitan species, 1 South - Palaearctic species, a Eurasian species, 1 West - Palaearctic species and 1 Holarctic species.

Considering the type of diet, they are 12 zoophagous species, 1 phytophagous species, 1 mycophagous species and 1 species feeds both on plants and fungus.

Since insects of Coccinellidae family shows significant differences regarding diet, they can be a good barometer of biodiversity.
Coccinellidae species have not been able to maintain a low population level of aphids, but they represented the largest group of predators.

\section{REFERENCES}

1. Anderson JME (1982). Seasonal habitat utilization and food of the ladybirds Scymnodes lividigaster and Leptothea galbula Coleoptera Coccinellidae. Australian Journal of Zoology 30:59-70.

2. Ansari Pour A, Shakarami J (2012). Recognition of ladybirds fauna (Col: coccinellidae) in the alfalfa fields of Khorramabad. Journal of Animal \& Plant Science 22(4):939-943.

3. Debach P (1974). Biological control by natural enemies. Cambridge University Press, Cambridge

4. Giorgi JA, Vandenberg NJ, McHugh JV, Forrester J, Ślipiński A, Miller KB, Shapiro LR, Whiting MF (2009). The evolution of food preferences in Coccinellidae. Biological Control 51:215-231

5. Gordon R (1985). The Coccinellidae (Coleoptera) of America North of Mexico. J. Entomol. Soc. 93(1):1-912

6. Hodek I (1973). Biology of Coccinellidae. Academia, Prague

7. Hodek I (1996). Food relations. In: Hodek I, Honek A (Eds.), Ecology of Coccinellidae. Kluwer Academic Publishers, Dordrecht, 143-238 pp.

8. Jafari R, Fursch H, Zarei M (2013). A checklist of the Scymninae (Coleoptera: Coccinellidae) of Iran. International Research Journal of Applied and Basic Sciences 4(12):4055-4061 
9. Khormizi Zare M, Biranvand A, Shakarami J (2013). The faunistic survey of lady beetles (Coleoptera, Coccinellidae) in the Mehriz region (Yazd Province), Iran. Bull. Iraq nat. Hist. Mus. 12(4):43-51

10. Lawrence JF, Newton AF (1995). Families and subfamilies of Coleoptera (with selected genera, notes, references and data on family-group names). In: Pakaluk J, Slipinski SA (Eds.), Biology, phylogeny and classification of Coleoptera: papers celebrating the 80th birthday of Roy A Crowson. Volume 2. Museum i Instytut Zoologii PAN, Warsaw, 779$1006 \mathrm{pp}$.

11. Lisenchi Murariu Camelia, Andriev Sorina Octavia (2008) The biodiversity of ladybirds (Coleoptera: Coccinellidae) in some alfalfa crops from the north of Moldavia. Analele Științifice ale Universității „Al. I. Cuza” Iași, s. Biologie animal, tom LIV

12. Lövei GL (1981). Coccinellid community in a apple orchard bordering a Deciduous forest. Acta Phytopathologica Academiae Scientiarum Hungaricae 16(1-2):143-150

13. Lundgren JG (2009). Relationships of Natural Enemies and Non-prey Foods. Springer International, Dordrecht

14. Majerus MEN (1994). Ladybirds. Ed. Harper Collins London, $359 \mathrm{pp}$.

15. Majka CG \& McCorquodale DB (2010). Ladybird beetles (Coleoptera: Coccinellidae) of the Atlantic Maritime Ecozone. In Assessment of Species Diversity in the Atlantic Maritime Ecozone. Ed. DF McAlpine and IM Smith. NRC Research Press, Ottawa, Canada, 436-452 pp.

16. Michels GJ (1987). A checklist of the coccinellidae (coleoptera) of Wyoming. The Coleopterist Bulletin 41(3):249-255

17. Moreton BD (1969). Ladybirds and spider mites. In: Beneficial insects and mites. Her Majesty, Stationary Office London. Ministry of Agriculture, Fisheries and Food. Bulletin 20:15-20
18. Moser SE, Harwood JD, Obrycki J (2008). Larval feeding on bt hybrid and non-bt corn seedlings by Harmonia axyridis (Coleoptera: Coccinellidae) and Coleomegilla maculate (Coleoptera: Coccinellidae). Environmental Entomology 37:525-533

19. Pemberton RW, Vandenberg NJ (1993). Extrafloral nectar feeding by ladybird beetles (Coleoptera: Coccinellidae). Proceedings of the Entomological Society of Washington 95:139-151

20. Ricci C (1982). Sulla constituzione e funzione delle mandible delle mandiboile delle larvae di Tytthaspis sedecempunctata (L.) e Tytthaspis trilineata (Weise). Frustula Entomologica 3:205-212

21. Ricci C, Fiori G, Colazza S (1983). Regime alimentare dell'adulto di Tytthaspis sedecimpunctata (L.) (Coleoptera: Coccinellidae) in ambiente a influenza antropica primaria: prato polifita. In: Proceedings XIII Congresso Nazionale Italiano di Entomologia, Instituto di Entomologia Agraria e Apicoltura, Università di Torino, Turín, 691-697 pp.

22. RicciC(1986). FoodstrategyofTytthaspissedecimpunctata (L.) in different habitats. In: Hodek I (Ed.), Ecology of Aphidophaga. Proceedings of a Symposium held at Zvíkovské Podhradí. Academia, Prague, 211-216 pp.

23. Serafim Rodica și Maican Sanda (2004). Contributions to the knowledge of the coleopterans from the littoral of the Black Sea (Romania), Travaux du Musdurn National d'Histoire Naturelle ct Grigore Antipa, XLVIl:169-210

24. Thalji R (2006). Composition of Coccinellid Comunities in Suger Beet Fields in Vojvidina. Proc. Nat. Sci. 110:267273, Matica Srpska Novi Sad

25. Vandenberg NJ (2002). Coccinellidae Latreille 1807. In American Beetles. Volume 2. Polyphaga: Scarabaeoidea through Curculionoidea. Edited by RH Arnett Jr, MC Thomas, PE Skelley and JH Frank. CRC Press, Boca Raton, 371-389 pp. 